\title{
Knowledge and attitude towards surrogacy in medical students of Yarsi university and its review in the views of Islam
}

Rosihayati, YARSI Faculty of Medicine, JI Letjen Soeprapto Jakarta Pusat 10510, Indonesia.

Ferryal Basbeth, Teaching Staff of the Forensic Science Department of the Medical Faculty of YARSI University, Indonesia.

RS Qomariyah, Teaching Staff of the Department of Physiology, Medical Faculty, YARSI University, Indonesia. Zuhroni, Teaching Staff of the Department of Religion, Medical Faculty, YARSI University, Indonesia.

Citation: Rosihayati, Basbeth F, Qomariyah RS, Zuhroni. Knowledge and attitude towards surrogacy in medical students of Yarsi university and its review in the views of Islam. Int J Eth Trauma Victimology 2019; 5(1):34-38. doi.org/10.18099/ijetv.v5i1.5.

Article history

Received: Dec 24, 2018

Received in revised form: August 19, 2019

Accepted: Sept 13, 2019

Available online: Nov 10, 2019

Corresponding author

Ferryal Basbeth

Teaching Staff of the Forensic Science Department of the Medical Faculty of YARSI University

Phone: +62-21 4206676 ext. 3103

Email: basbethf@gmail.com

\begin{abstract}
Background: According to Clara Watson, surrogacy is the practice of a woman bearing a child for another woman with the aim of giving the baby to its biological mother on birth. One of the reasons for surrogacy is the person preferring to be single while wanting to have a baby of his/her own. The practice is prevalent abroad. Some countries have prohibited surrogacy while few others have legalized it. In the view of Islam, the practice is forbidden.

Purpose: To know the knowledge and attitude of Medical Students of YARSI University class of 2015 about surrogacy.

Method: The research method used was descriptive crosssectional study. Purposive sampling method was used for this purpose.

Result: A total of 180 students participated in the study. The results of knowledge regarding surrogate mother were good (27.2\%), knowledgeable enough (51.1\%), less knowledgeable $(27.2 \%)$ and the majority $(52.8 \%)$ had an attitude not approving of the practice of surrogate mother.

Conclusion: In this research the majority of students from the Medical Faculty, YARSI University class of 2015 had sufficient knowledge and an attitude that is not approving of the practice of surrogate mother. In the Islamic view, all forms of surrogate mother are forbidden. Surrogacy by sperm or ovum donation from another person or a husband who has died is forbidden because it will cause nasal (family lineage) mixing and will trigger a dispute that is not in accordance with Islamic law.
\end{abstract}

Keywords: Knowledge and attitude; YARSI Medical students; surrogacy; surrogate mother; Islamic views.

(C) IJETV. All rights reserved

\section{Introduction}

Surrogacy is often defined as the practice of a woman bearing a child for another woman with the aim of giving the baby to its biological mother on birth. This practice is carried out on the agreement of both parties through contracts including Surrogate mother, women who conceive and give birth to babies and other parties usually a woman who cannot get pregnant or a woman who is able to conceive but does not want to conceive her own baby (1), career-oriented women with their professional constraints (e.g. actors, models) even single and homosexual couples can realize their dreams of becoming parents through surrogacy (2).To evaluate the attitude and knowledge of medical students towards surrogacy as an assisted reproductive instrument, an online survey was sent to medical students from universities in the UK, 185 anonymous replies were received. As many as $72.2 \%$ agreed with surrogacy 
as an assisted reproductive tool; $43.9 \%$ thought mothers who intend to become parents are legitimate mothers at birth; $15.2 \%$ thought that surrogacy arrangements can be enforced by law; $29.2 \%$ did not have any opinion. There is no difference in knowledge about surrogacy among students who have studied midwifery and gynecology compared to those who did not study it. Medical students are generally tolerant in their attitude towards surrogacy (3).

There are still many cases of surrogate mother currently occurring overseas, such as India, Pakistan, Bangladesh and China. In some countries, especially America and Britain, surrogacy is legally enforceable but with agreement between the two parties (4).

Legislation in various countries is different. In Europe, surrogacy is not officially permitted in Austria, Bulgaria, Denmark, Finland, France, Germany, Italy, Malta, Norway, Portugal, Spain and Sweden. Altruistic or noncommercial surrogacy is allowed in Belgium, Greece, the Netherlands and England. Some European countries, such as Poland and the Czech Republic, currently do not have laws on surrogacy (5).

Indonesia does not have specific rules regarding surrogate mother therefore the implementation of surrogate mother relating to surrogacy agreements is not possible in Indonesian jurisdiction. Indonesia prohibits all actions related to surrogate mother because it is contrary to the norms of adat, religion and decency (6).

In the view of Islam, Assisted Reproductive Technologies (ART) can be used if done by a husband and wife. It is not justified by Islam if there is a "womb rental", that is, the embryo is implanted in the womb of a woman other than the legal wife of the couple. Islam is very guarding so that children who are born later do not have nasab (family lineage) mixing. Islam also forbids taking sperm or egg cells from a legitimate husband or wife, unless one of them has died (7).

With this background information, the authors were interested in conducting a study to evaluate the knowledge and attitudes of medical students of the class of 2015 of the YARSI University Medical Faculty towards surrogacy.

\section{Material and Methods}

This type of research is a descriptive observational research with a cross sectional research design. The study population of this research were Medical
Faculty students of YARSI University class of 2015 with a population of active female students consisting of 239 people. The sample taken was class A and Class B of Medical Faculty Students of YARSI University class of 2015 who met the inclusion criteria (students who were active in the Medical Faculty of YARSI University, were willing to be respondents, students class of 2015 semester VI, students who were passed Ethics Block) and exclusion criteria (not willing to be respondents, students class of 2015 who are not semester VI, attendance is not fulfilled the requirements). The technique used for sampling was purposive sampling. Data collection was done using a questionnaire. Analysis of univariate data using the SPSS version 22.0 program.

\section{Result and Discussion}

One hundred eighty medical students of the YARSI university of the 2015 batch participated in the study. Table 4.1. shows the participants' distribution based on age of the respondents. The maximum respondents were from the 21-25-yearold age group ( $n=99,55 \%)$.

Table 1. Respondents' Frequency Distribution by Age

\begin{tabular}{lcc}
\hline Age & $\mathrm{N}$ & $\%$ \\
\hline $18-20$ Years old & 81 & 45.0 \\
$21-25$ Years old & 99 & 55.0 \\
\hline Total & 180 & 100.0 \\
\hline
\end{tabular}

Table 2 shows the participants' distribution based on sex of the respondents. Majority of the respondents were of the female sex $(n=141$, 78.3\%).

Table 2. Respondents' Distribution by Sex

\begin{tabular}{lll}
\hline Sex & $\mathrm{N}$ & $\%$ \\
\hline Male & 39 & 21.7 \\
Female & 141 & 78.3 \\
Total & 180 & 100.0 \\
\hline
\end{tabular}

Table 3 shows the number of responses for each item of the questionnaire. Maximum figures for correct and incorrect responses were 172 (95.9\%) for item no 3 and 152 (84.4\%) for item number 10 respectively. 
As seen from Table 3, 71.1\% of respondents correctly answered the question of who is a surrogate mother as one who leases her womb for bearing the child of another woman. The incorrect responses to this question (28.9\%) included borrowing the womb", "exchanging the womb"

Table 3: Respondents' Frequency Distribution by Knowledge Question Items

\begin{tabular}{|c|c|c|c|c|}
\hline \multirow{2}{*}{$\begin{array}{l}\text { Qomariyah } \\
\text { RS, } \\
\text { Zuhroni. } \\
\text { Qomariyah } \\
\text { RS, } \\
\text { Zuhroni. }\end{array}$} & \multicolumn{2}{|c|}{ Qomariyah RS, Zuhroni. } & \multicolumn{2}{|c|}{$\begin{array}{l}\text { Qomariyah } \\
\text { RS, } \\
\text { Zuhroni. }\end{array}$} \\
\hline & $\begin{array}{l}\text { Qomariyah } \\
\text { RS, } \\
\text { Zuhroni. }\end{array}$ & $\begin{array}{l}\text { Qomariyah } \\
\text { RS, } \\
\text { Zuhroni. }\end{array}$ & $\mathrm{N}$ & $\%$ \\
\hline $\begin{array}{l}\text { Qomariyah } \\
\text { RS, } \\
\text { Zuhroni. }\end{array}$ & $\begin{array}{l}\text { Qomariyah } \\
\text { RS, } \\
\text { Zuhroni. }\end{array}$ & $\begin{array}{l}\text { Qomariyah } \\
\text { RS, } \\
\text { Zuhroni. }\end{array}$ & 52 & $28.9 \%$ \\
\hline $\begin{array}{l}\text { Qomariyah } \\
\text { RS, } \\
\text { Zuhroni. }\end{array}$ & $\begin{array}{l}\text { Qomariyah } \\
\text { RS, } \\
\text { Zuhroni. }\end{array}$ & $\begin{array}{l}\text { Qomariyah } \\
\text { RS, } \\
\text { Zuhroni. }\end{array}$ & 62 & $34.4 \%$ \\
\hline $\begin{array}{l}\text { Qomariyah } \\
\text { RS, } \\
\text { Zuhroni. }\end{array}$ & $\begin{array}{l}\text { Qomariyah } \\
\text { RS, } \\
\text { Zuhroni. }\end{array}$ & $\begin{array}{l}\text { Qomariyah } \\
\text { RS, } \\
\text { Zuhroni. }\end{array}$ & 8 & $4.4 \%$ \\
\hline $\begin{array}{l}\text { Qomariyah } \\
\text { RS, } \\
\text { Zuhroni. }\end{array}$ & $\begin{array}{l}\text { Qomariyah } \\
\text { RS, } \\
\text { Zuhroni. }\end{array}$ & $\begin{array}{l}\text { Qomariyah } \\
\text { RS, } \\
\text { Zuhroni. }\end{array}$ & 94 & $52.2 \%$ \\
\hline $\begin{array}{l}\text { Qomariyah } \\
\text { RS, } \\
\text { Zuhroni. }\end{array}$ & $\begin{array}{l}\text { Qomariyah } \\
\text { RS, } \\
\text { Zuhroni. }\end{array}$ & $\begin{array}{l}\text { Qomariyah } \\
\text { RS, } \\
\text { Zuhroni. }\end{array}$ & 13 & $7.2 \%$ \\
\hline $\begin{array}{l}\text { Qomariyah } \\
\text { RS, } \\
\text { Zuhroni. }\end{array}$ & $\begin{array}{l}\text { Qomariyah } \\
\text { RS, } \\
\text { Zuhroni. }\end{array}$ & $\begin{array}{l}\text { Qomariyah } \\
\text { RS, } \\
\text { Zuhroni. }\end{array}$ & 73 & $40.6 \%$ \\
\hline $\begin{array}{l}\text { Qomariyah } \\
\text { RS, } \\
\text { Zuhroni. }\end{array}$ & $\begin{array}{l}\text { Qomariyah } \\
\text { RS, } \\
\text { Zuhroni. }\end{array}$ & $\begin{array}{l}\text { Qomariyah } \\
\text { RS, } \\
\text { Zuhroni. }\end{array}$ & 42 & $23.3 \%$ \\
\hline $\begin{array}{l}\text { Qomariyah } \\
\text { RS, } \\
\text { Zuhroni. }\end{array}$ & $\begin{array}{l}\text { Qomariyah } \\
\text { RS, } \\
\text { Zuhroni. }\end{array}$ & $\begin{array}{l}\text { Qomariyah } \\
\text { RS, } \\
\text { Zuhroni. }\end{array}$ & 58 & $32.2 \%$ \\
\hline
\end{tabular}

Qomariyah Qomariyah Qomariyah $114 \quad 63.3 \%$ RS, RS, RS,

Zuhroni. Zuhroni. Zuhroni.

Qomariyah Qomariyah Qomariyah 152 84.4\% RS, RS, RS,

Zuhroni. Zuhroni. Zuhroni.

and "leasing the mother". This was even though most of the respondents had studied and learned about the surrogate mother.

On the item question about the reason for doing surrogate mother, the respondents who answered correctly were $65.6 \%$ with the correct reasons given as infertility, same-sex couples, and the lady not wanting to bear her own child. This proves that most respondents know why this can be done by the parties concerned. Majority (95.6\%) of the respondents knew that surrogacy is achieved by using In Vitro Fertilization (IVF).

From the responses, it is evident that there is still a lack of knowledge of respondents regarding the countries where surrogacy is practiced.

On the question item about Islamic law regarding the surrogacy, $92.8 \%$ respondents correctly answered that Islam forbids surrogate mothers own practice. Further, a majority of the responses (76.7\%) incorrectly pointed out that Islam forbids surrogacy even if the surrogate mother is also the wife of the man. The reason why Islam forbids conception in the womb of the wife using her late husband's sperm which has been preserved following his death, is because after death in syar' $i$ there has been a divorce (death divorce) with his wife, and so their status is no longer that of a husband and wife. This reason was not known to a good number of respondents (67.8\%).

As far as knowledge of Indonesian law regarding surrogacy is concerned, $76.7 \%$ of respondents answered correctly that Indonesia does not legally permit it as per regulations in Law number 36 of 2009 concerning Health in Article 27 (8).

Table 4 shows that the knowledge of the Medical Faculty Students of YARSI University class of 2015 regarding surrogacy is adequate in as many as 92 people (51.1\%).

Table 4: Respondent's Frequency Distribution by Knowledge Category

\begin{tabular}{lcc}
\hline Knowledge Category & $\mathrm{N}$ & $\%$ \\
\hline Less Knowledge & 49 & 27.2 \\
Enough Knowledge & 92 & 51.1 \\
Good Knowledge & 39 & 21.7 \\
\hline Total & 180 & 100.0 \\
\hline
\end{tabular}

In this case the researcher wanted to find out the respondent's attitude towards the surrogate mother through several statements categorizing it into good and bad attitudes. Calculations for attitudinal variables were obtained that the provisions of the Mean set were 33.71. So for each respondent whose score was summed, it was found that the score of more than 33.72 had a 
good attitude and a score that was less than 33.71 had a bad attitude.

The attitudinal statement for each item of the questionnaire is discussed in this research. In statement number two respondents strongly agree that surrogate mother is an act that violates Islamic law. In statement number four, respondents did not agree if in the case of Altruistic surrogacy (where surrogate does not get money for the pregnancy / release of the child) legally in the Australian Capital Territory can still be allowed. In statement number six, respondents are not very sure whether the practice of surrogacy is very popular in India for couples around the world because of the relatively lower cost. In attitude statement number eight, respondents strongly disagree that men with polygamy should be allowed to use surrogacy technique to bear a child with another wife. And finally in statement number ten, the respondents were unsure whether the embryo deposited in the womb of the surrogate mother of a legitimate husband and wife, genetically after birth became the biological child of the couple.

Statements number one, three, five, seven and nine displayed the negative attitude. In statement number one, respondents agree that surrogate mother is not the best choice for couples who have infertility. In statement number three, the respondent did not agree to conduct a surrogate mother to help a partner with infertility. In statement number five, respondents strongly agree that Indonesia should not allow surrogacy. In statement number seven, respondents strongly agree that similar couples may not conduct a surrogate mother. In statement number nine, the respondents strongly agreed that Jeremy Teti's statement was wrong about the deviant / homosexual sex offender still being able to get offspring by surrogate mother.

Table 5: Respondent Frequency Distribution by Attitude Category

\begin{tabular}{lll}
\hline Attitude Category & $\mathrm{N}$ & $\%$ \\
\hline Good Attitude & 95 & 52.8 \\
& & \\
Bad Attitude & 85 & 47.2 \\
\hline Total & 180 & 100.0 \\
\hline
\end{tabular}

Table 5 shows that the attitude concerning surrogate mother in 180 Medical Faculty students of YARSI University class of 2015. More people have good attitudes $(95,52.8 \%)$.

\section{Conclusion}

Based on the results of the research that has been done, it can be concluded that: Knowledge and attitude towards the surrogate mother of the YARSI University Faculty of Medicine students of class of 2015 obtained a description of the results of knowledge about surrogate mother both (21.7\%), sufficient knowledge (51.1\%), and lack of knowledge $(27.2 \%)$. In this study, it was also obtained a picture of the results of a good attitude disagreeing with the existence of a surrogate mother $(52.8 \%)$ and a bad attitude including still doubting and agreeing to the surrogate mother (47.2\%). Based on Islamic views, all forms of surrogate mother are forbidden. Conducting a surrogate mother by making a sperm or ovum donation from another person or from another wife - Nasab children born from surrogate mother disagree between the owner of the ovum or the owner of the uterus. But when viewed from a review of some of the Koran nasab the child is more to the owner of the womb.

\section{Suggestion}

Based on the results of the research that has been done, it is found that some things should be improved, namely the researchers are expected to understand more about surrogate mother and address all forms of surrogate mother practice so that coverage can be broader and reconsider the place of research thoroughly. Respondents are expected to be able to find out more about the surrogate mother and consider good attitudes to deal with this case.

\section{Conflict of Interest}

None Declared

\section{References}

1. Watson C. Womb Rentals and BabySelling: Does Surrogacy Undermine the Human Dignity and Rights of the Surrogate Mother and Child? New Bioeth. 2016;22(3):212-228.

2. Kaur J. Surrogate motherhood a socio legal study with special reference to state of Punjab and union territory Chandigarh. 2016;

3. Bruce-Hickman K, Kirkland L, Ba-Obeid T. The attitudes and knowledge of medical students towards surrogacy. J Obstet Gynaecol. 2009;29(3):229-232. 
4. Desriza R. Surrogate Mother dalam Perspektif Etika dan Hukum: Bolehkah Sewa Rahim di Indonesia. Bogor: Gramedia; 2012.

5. Söderström-Anttila $V$, Wennerholm U-B, Loft A, Pinborg A, Aittomäki K, Romundstad LB, et al. Surrogacy: outcomes for surrogate mothers, children and the resulting families-a systematic review. Hum Reprod Update. 2016;22(2):260-276.

6. Judiasih SD, Dajaan SS. Aspek Hukum Surrogate Mother Dalam Perspektif Hukum Indonesia. J Bina Mulia Huk. 2017;1(2):141-150.

7. Oetarjo D, Qomariyah dan S. Isu Etika Dalam Penelitian di Bidang Kesehatan. Jakarta: Universitas YARSI; 2013.

8. Husni T. Hukum Sewa Rahim dalam Bayi Tabung.Yogyakarta: Aswaja Pressindo. Yogyakarta: Aswaja Pressindo; 2015. 